\title{
Using the Interactive Web to Enhance Teaching and Learning
}

\author{
N. Soliman \\ The British University in Egypt, English Department, Cairo, Egypt
}

\begin{abstract}
Blended learning is spreading in a lot of institutions nowadays. There is a need to use technology together with face to face teaching in order to motivate students to learn. Some students use technology to socialize with friends, show off or just chat to fill up their spare time. They are overwhelmed with any new technological product that becomes available in their country and compete to be the first to buy the latest mobile phone, eyepod or mp3. There is a need to make use of their interest in technology but to try to gear it towards learning and doing research that will lead to the enhancement and development of their future careers.
\end{abstract}

Keywords Technology, E-learning, Interactive, Blended Learning

\section{Introduction}

My class is a group of undergraduate students belonging to different faculties and this course level is their final English module .My project class is (A) a group of students whose ages range between 18-22 and they are a mixture of males and females. The students' English level is advanced and they are all computer wizards. They are enrolled in different faculties at the British University in Egypt.

The module's objective (ABCD) is as follows: By the end of the term students (A) should be able to read academic texts; to write analytical \& persuasive essays; develop critical reading and thinking skills; read evaluate and synthesise from a variety of sources; present research findings in a presentation; use grammar effectively to produce appropriate academic style and finally to develop listening note taking skills from documentaries (B). This should be achieved when students are requested to write two problem solution essays (1000 words)(C) and they are expected to complete them before the deadline; to use academic style and to at least score (40\%)which is the passing score (D). The students need to take this Advanced Writing course before they graduate.

The students' needs are to be able to use academic English in their different majors because English is the medium of instruction. Thus they are supposed to use English to study the content of their majors and not mastering the language will inevitably affect their performance in their faculties.

With regards to technology, all classes are equipped with Internet access. This facilitates using videos, PowerPoint,

* Corresponding author

nagwa.soliman@bue.edu.eg (N. Soliman)

Published online at http://journal.sapub.org/edu

Copyright (C) 2012 Scientific \& Academic Publishing. All Rights Reserved
E-Learning or any other activity that requires Internet access. The teacher is equipped with a computer in the classroom and has Internet access and speakers. The students have access to school computers in the labs. Teachers can take students to the computer labs after prior reservation.

\section{Issue or Problem That Started The Problem}

My students' problem is lack of proper use of technology. In other words, it is used as a means of entertainment to play games to catch up on friends' latest news. You may find them on Facebook looking at photos that show where they went during holidays or their latest outing together. The purpose behind this may not be just to keep in touch with your friends, but to show off. This may not seem a real problem especially to teenagers, but they tend to waste a lot of time on this, so they may stay in front of Facebook or play on-line games and neglect their assignments and projects. Thus, Face Book, on-line games, chatting, and Skype (on-line technology) to teenagers are a means of showing off and socializing with their friends.

The Internet technology that is used is mainly used by the teacher in the classroom, but not by the students in relation to this course. Students, as was mentioned before, use technology to chat, play on-line games or text messages on their BBMs or log on Face Book. This is not just on week-ends or during their leisure time, it is most of the time and technology is hardly used seriously to do research or read on-line. So the problem now is how to make students use Internet technology before they attend class (pre-reading or pre-discussions) so that they could be prepared for the class and at the same time be motivated to attend and learn. 
Moreover, how to use technology in games and activities related to the module's objectives that would make students simultaneously enjoy and learn.

\section{Proposed Solution and Expected Response}

The solution is to encourage students to use technology with their studies. This I plan to do by using six techniques: Firstly, assigning weekly pre-readings on-line that will be discussed in class and grades will be assigned for this task. Secondly, I will use the following links:

http://www.udel.edu/pblc/samples/

https://primus.nss.udel.edu/ $\mathrm{Pbl} /$

which have sample problems and solutions. I will ask students to form groups and pick a problem and try to find a different solution. Students before I took this course used to pick a problem from a list of problems that we give them, but now they will go on-line and read about similar problems and their solutions to see how others abroad think critically and their approach to the solution. Thirdly, they could even join existing projects or invite classes to participate in their projects. This could be accomplished by asking students to form e-pals and try to take part in a project with other students abroad and report the results of this project to the whole class in the form of a presentation. In other words, students instead of working on their own finding sources, synthesizing, citing and then writing, can $\log$ on the different sample problem-based projects and collaborate with e-Pals who worked or are working on similar projects. This I believe gives their work authenticity and they will be motivated to work hard as other students abroad. This worldwide e-communication is expected to motivate them and it should lead to their retaining information Fourthly, I will use ANVILL to create discussions using audio and video upload to boost interaction and critical thinking. For example before the term starts we usually have our course description with our weekly plans ready, but I plan next term to prepare in a different way. Before the term starts I will have all the on-line material for the course ready and uploaded on E-learning. I can have the lessons created on ANVILL where students will be able to watch a video and react using audio or audio and video. I could have a picture, a hyperlink to articles that they should read before coming to class. They will be asked to react orally using audio and in written form when necessary. Moreover, I could upload interactive activities which could be prepared through Smile using CLEAR or Hot Potatoes or ANVILL that students can work on at home independently and then I could give them feedback. My goal here is to have students come to class prepared so that class time could be for discussion through group work and pair work. Moreover, students will be encouraged and will develop the habit of working independently to enhance their skills. Fifthly, I will have students create reflective blogs where they can express their thoughts concerning what they learnt, and what they liked or disliked about the course. This could be like an internal feedback that I get right at the end of the course and they could also comment on their peers' blogs to see whether or not they have similar views. This will be somewhat different than the regular formal evaluations that students fill out near the end of the term and are submitted to the head of the department. Last but not least, the final essay or project will be introduced in week three and the components will be divided in tasks all through the term, so that students will not have to cram their summative project in two weeks as was the case before I took this course. Furthermore, peer editing will be done on-line which gives students enough time to edit and submit the form on e-learning. Before it was done in class and not all students were present and they did not all take part in editing. I will ask them to choose partners to give them some autonomy and they will be obliged to meet the deadlines with regards to choosing a partner, peer editing and submitting their final draft.

What I will try is totally different from what was done before because students before I started this project did not collaborate with others abroad to check other authentic suggestions to projects that are similar to theirs. We used to encourage them to find previous solutions and to mention their cons and pros and then to come up with their own suggested solution and to persuade the reader with its power in solving the problem. However, they failed to come up with feasible solutions because they did not have access to the e-pal system and were not guided to consult projects worldwide to get a better picture of how problems are solved in different places in the world.

\section{Expected Student Response}

The expected response is that students will be motivated to use technology with their studies and technology will not only be regarded as a means to pass their leisure time or to communicate with their friends, but also as a learning tool that could enhance their skills and understanding. I expect this response because what they are requested to do will include not just reading which some do not enjoy, but they will record their answers and they will upload videos. This I believe will strike a chord and will encourage them to participate in the activity. A lot of students complain that there is not enough speaking in their EAP classes, so this will allow them to record and speak and have their voice heard by them and the teacher. The on-line reading of articles before the class will enable them to discuss what they read in class.

The expected response is that students will be motivated to use technology with their studies and technology will not only be regarded as a means to pass time or to chat with their friends, but also as a learning tool that could enhance their skills and understanding. Less time will be wasted on Internet socializing, especially when their 'Independent Learning' tasks are graded. The aim here is not to terminate e-socializing with friends and family completely as this may breed humans who are closer to being inanimate objects and 
similar somehow to machines with no feelings or emotions, and this would contradict with the Middle Eastern culture and tradition and therefore would be impossible to achieve.

\section{Reflection}

If students are well prepared and come to class highly motivated, this will affect their attitude in class and they will become engaged and interactive with one another and with their teacher as well. For example, when they use the Voiceboards on the ANVILL program they will be able to express themselves orally and could also use video to voice their opinion, thus using the language in a non-threatening atmosphere which is expected to boost their language skills and autonomy. Moreover, listening to their teacher on T-Casts on ANVILL will also enable the students to correct their pronunciation while trying to speak like their teacher.

Having students use technology in reading on-line articles, recording their opinions and reactions via audio and video, and writing their views will surely lift the focus in class from the teacher to the students. This is because students will in that case come to class to discuss, analyse and comment on what they have read. Moreover, teachers will be able to know from the recording which students accomplished the requested task and those who did not bother to do them. Marks will be allocated to every single task whether it was assigned pre-during or post. If students are well prepared and come to class highly motivated, this will affect their attitude in class and they will become engaged and interactive with one another and with their teacher as well. Furthermore, their attendance is expected to improve, as they would not get bored in class and they will make use of the technology that is provided in class, in labs and at home.

\section{Conclusions}

Technology can indeed create an excellent atmosphere for students to learn inside and outside the classroom. It can boost their motivation, make them well prepared and interested in attending classes. In addition, technology is a means that enables students to become autonomous learners.

The overall suggestion for teachers as a result of the project is that they need to pre-prepare their course description making sure to make the utmost use of technology to enhance their course materials and syllabus to easily achieve their ILOs (Intended Learning Objectives)

\section{Appendix}

The following is a rubric that will be used with the students to follow up on their use of technology:

Collaborative Work Skills. Using Technology in Learning

\begin{tabular}{|c|c|c|c|c|}
\hline \multicolumn{5}{|c|}{$\begin{array}{l}\text { Teacher Name: Dr. Soliman } \\
\text { Student Name: }\end{array}$} \\
\hline CATEGORY & 4 & 3 & 2 & 1 \\
\hline Blogs & $\begin{array}{c}\text { Routinely provides useful ideas } \\
\text { when participating in the group } \\
\text { and in classroom discussion. A } \\
\text { definite leader who contributes } \\
\text { a lot of effort. }\end{array}$ & $\begin{array}{c}\text { Usually provides useful ideas } \\
\text { when participating in the group } \\
\text { and in classroom discussion. A } \\
\text { strong group member who tries } \\
\text { hard! }\end{array}$ & $\begin{array}{c}\text { Sometimes provides useful ideas } \\
\text { when participating in the group } \\
\text { and in classroom discussion. A } \\
\text { satisfactory group member who } \\
\text { does what is required. }\end{array}$ & $\begin{array}{l}\text { Rarely provides useful ideas } \\
\text { when participating in the } \\
\text { group and in classroom } \\
\text { discussion. May refuse to } \\
\text { participate. }\end{array}$ \\
\hline $\begin{array}{l}\text { Project Based } \\
\text { Learning PBL }\end{array}$ & $\begin{array}{l}\text { Actively looks for and suggests } \\
\text { solutions to problems. }\end{array}$ & $\begin{array}{c}\text { Refines solutions suggested by } \\
\text { others. }\end{array}$ & $\begin{array}{l}\text { Does not suggest or refine solu- } \\
\text { tions, but is willing to try out } \\
\text { solutions suggested by others. }\end{array}$ & $\begin{array}{l}\text { Does not try to solve prob- } \\
\text { lems or help others solve } \\
\text { problems. Lets others do the } \\
\text { work. }\end{array}$ \\
\hline e-Pals & $\begin{array}{l}\text { Never is publicly critical of the } \\
\text { project or the work of others. } \\
\text { Always has a positive attitude } \\
\text { about the task(s). }\end{array}$ & $\begin{array}{l}\text { Rarely is publicly critical of the } \\
\text { project or the work of others. } \\
\text { Often has a positive attitude } \\
\text { about the task(s). }\end{array}$ & $\begin{array}{c}\text { Occasionally is publicly critical of } \\
\text { the project or the work of other } \\
\text { members of the group. Usually } \\
\text { has a positive attitude about the } \\
\text { task(s). }\end{array}$ & $\begin{array}{l}\text { Often is publicly critical of } \\
\text { the project or the work of } \\
\text { other members of the group. } \\
\text { Often has a negative attitude } \\
\text { about the task(s). }\end{array}$ \\
\hline $\begin{array}{l}\text { Time-manage } \\
\text { ment }\end{array}$ & $\begin{array}{c}\text { Routinely uses time well } \\
\text { throughout the project to ensure } \\
\text { things get done on time. Group } \\
\text { does not have to adjust dead- } \\
\text { lines or work responsibilities } \\
\text { because of this person's pro- } \\
\text { crastination. }\end{array}$ & $\begin{array}{l}\text { Usually uses time well } \\
\text { throughout the project, but may } \\
\text { have procrastinated on one } \\
\text { thing. Group does not have to } \\
\text { adjust deadlines or work re- } \\
\text { sponsibilities because of this } \\
\text { person's procrastination. }\end{array}$ & $\begin{array}{c}\text { Tends to procrastinate, but always } \\
\text { gets things done by the deadlines. } \\
\text { Group does not have to adjust } \\
\text { deadlines or work responsibilities } \\
\text { because of this person's procras- } \\
\text { tination. }\end{array}$ & $\begin{array}{l}\text { Rarely gets things done by } \\
\text { the deadlines AND group has } \\
\text { to adjust deadlines or work } \\
\text { responsibilities because of } \\
\text { this person's inadequate time } \\
\text { management. }\end{array}$ \\
\hline $\begin{array}{l}\text { Quality of } \\
\text { Work }\end{array}$ & $\begin{array}{c}\text { Provides work of the highest } \\
\text { quality. }\end{array}$ & Provides high quality work. & $\begin{array}{l}\text { Provides work that occasionally } \\
\text { needs to be checked/redone by } \\
\text { other group members to ensure } \\
\text { quality. }\end{array}$ & $\begin{array}{l}\text { Provides work that usually } \\
\text { needs to be checked/redone } \\
\text { by others to ensure quality. }\end{array}$ \\
\hline Pride & Work reflects this studentl's best & Work reflects a strong effort & Work reflects some effort from & Work reflects very little \\
\hline
\end{tabular}




\begin{tabular}{|c|c|c|c|c|}
\hline & efforts. & from this student. & this student. & $\begin{array}{l}\text { effort on the part of this } \\
\text { student. }\end{array}$ \\
\hline Pre-readings & $\begin{array}{l}\text { Brings needed materials to class } \\
\text { and is always ready to work. }\end{array}$ & $\begin{array}{c}\text { Almost always brings needed } \\
\text { materials to class and is ready to } \\
\text { work. }\end{array}$ & $\begin{array}{l}\text { Almost always brings needed } \\
\text { materials but sometimes needs to } \\
\text { settle down and get to work }\end{array}$ & $\begin{array}{l}\text { Often forgets needed mate- } \\
\text { rials or is rarely ready to get } \\
\text { to work. }\end{array}$ \\
\hline $\begin{array}{l}\text { Monitors } \\
\text { Group Effec- } \\
\text { tiveness }\end{array}$ & $\begin{array}{c}\text { Routinely monitors the effec- } \\
\text { tiveness of the group, and makes } \\
\text { suggestions to make it more } \\
\text { effective. }\end{array}$ & $\begin{array}{c}\text { Routinely monitors the effec- } \\
\text { tiveness of the group and works } \\
\text { to make the group more effec- } \\
\text { tive. }\end{array}$ & $\begin{array}{l}\text { Occasionally monitors the effec- } \\
\text { tiveness of the group and works to } \\
\text { make the group more effective. }\end{array}$ & $\begin{array}{l}\text { Rarely monitors the effec- } \\
\text { tiveness of the group and } \\
\text { does not work to make it } \\
\text { more effective. }\end{array}$ \\
\hline $\begin{array}{l}\text { Working with } \\
\text { Others }\end{array}$ & $\begin{array}{c}\text { Almost always listens to, shares } \\
\text { with, and supports the efforts of } \\
\text { others. Tries to keep people } \\
\text { working well together. }\end{array}$ & $\begin{array}{l}\text { Usually listens to, shares, with, } \\
\text { and supports the efforts of } \\
\text { others. Does not cause } \\
\backslash \text { "waves } \backslash \text { " in the group. }\end{array}$ & $\begin{array}{l}\text { Often listens to, shares with, and } \\
\text { supports the efforts of others, but } \\
\text { sometimes is not a good team } \\
\text { member. }\end{array}$ & $\begin{array}{l}\text { Rarely listens to, shares with, } \\
\text { and supports the efforts of } \\
\text { others. Often is not a good } \\
\text { team player. }\end{array}$ \\
\hline $\begin{array}{l}\text { Focus on the } \\
\text { task }\end{array}$ & $\begin{array}{l}\text { Consistently stays focused on } \\
\text { the task and what needs to be } \\
\text { done. Very self-directed. }\end{array}$ & $\begin{array}{l}\text { Focuses on the task and what } \\
\text { needs to be done most of the } \\
\text { time. Other group members can } \\
\text { count on this person. }\end{array}$ & $\begin{array}{l}\text { Focuses on the task and what } \\
\text { needs to be done some of the time. } \\
\text { Other group members must } \\
\text { sometimes nag, prod, and task. } \\
\text { remind }\end{array}$ & $\begin{array}{l}\text { Rarely focuses on the task } \\
\text { and what needs to be done. } \\
\text { Lets others do the work. }\end{array}$ \\
\hline
\end{tabular}

\section{REFERENCES}

[1] Guo, Yan. Project-based ESL Education: Promoting Language and Content Learning. Retrieved from: http://www.atesl.ca/cmsms/home/newsletters/december-200 7/project-based-esl-education/

[2] Gaer, Susan. Less Teaching and More Learning. Retrieved from: http://www.ncsall.net/?id=385

[3] Gaer, Susan. The Student Projects Sampler . Retrieved from: http://susangaer.com/studentprojects/

[4] Interactive Lectures. Retrieved from:

[5] http://serc.carleton.edu/introgeo/interactive/howto.html

[6] Interactive Lectures Summaries of 36 formats. Retrieved from:

[7] http://www.thiagi.com/interactive-lectures.html

[8] Thanasoulas, Dimitrios. What is Learner Autonomy and How can it Be Fostered. The Internet TESL Journal, Vol. V1, No. 11, Nov. 200. Retrieved from:

[9] http://iteslj.org/Articles/Thanasoulas-Autonomy.html

[10] http://ylclab.uoregon.edu/groups/anvillhelp/wiki/13c0d/Cour se_Building__Management.html

[11] http://hotpot.uvic.ca/

[12] http://eolf.univ-fcomte.fr/index.php?page=technically-interes ting-hot-potatoes-pages

[13] http://www.toolsforeducators.com/

[14] http://bogglesworldesl.com/

[15] Video: http://www.youtube.com/watch?v=qQra4baNwP8 